\title{
Ellipsis
}

\section{The night after you break up with me (or whatever we're calling it)}

Maya Lowy

University of New Orleans

Follow this and additional works at: https://scholarworks.uno.edu/ellipsis

\section{Recommended Citation}

Lowy, Maya (2015) "The night after you break up with me (or whatever we're calling it)," Ellipsis: Vol. 42 , Article 16.

DOI: https://doi.org/10.46428/ejail.42.16

Available at: https://scholarworks.uno.edu/ellipsis/vol42/iss1/16

This Poetry is brought to you for free and open access by the Department of English and Foreign Languages at ScholarWorks@UNO. It has been accepted for inclusion in Ellipsis by an authorized editor of ScholarWorks@UNO. For more information, please contact scholarworks@uno.edu. 


\title{
The night after you break up with me (or whatever we're calling it) \\ Maya Lowy
}

\author{
Vassar Miller Poetry Award Honorable Mention
}

I make myself dinner for the first time in a long time.

I even have two burners going at once.

The door to the kitchen is closed, the door to the balcony

is open. I taste the sautée

as it cooks, I time the noodles by feel.

Everything is delicious, even the old fish.

Your sweat is still in my sheets from five days back, and you don't matter!

I chew the stems of the mustard greens

for their greenness: they taste sweet. 